\title{
TAKHRIJ HADIS KENCING BERDIRI
}

\author{
Fakhrurrozi \\ Program Studi Pendidikan Bahasa Arab STAI As-Sunnah Deli Serdang \\ Jl. Medan-Tg. Morawa, Km. 13, Gg. Darmo, Desa Bangun Sari, Tanjung Morawa, Deli Serdang. \\ ro.zi24@yahoo.co.id
}

\begin{abstract}
Abstrak: Hadis-hadis Nabi tentang kencing berdiri ditemukan di Kutub Tis`ah, kitab induk hadis yang sembilan, kecuali Muwatta' Imam Malik. Secara keseluruhan hadis-hadis tersebut bersumber dari jalur sanad Huzaifah Ibn alYaman. Penelitian ini memfokuskan diri pada hadis kencing berdiri yang ditakhrij oleh Imam ad-Darimi dalam kitabnya Sunan ad-Darimi. Penelitian ini dilakukan dengan metode kritik hadis sebagaimana telah ditentukan oleh ulama hadis dalam kitab-kitab ulumul hadis, yaitu dengan memeriksa lima kriteria kesahihan hadis pada jalur yang sedang diteliti. Dari hasil penelitian sanad terhadap hadis tersebut disimpulkan bahwa seluruh keriteria kesahihan sanad terdapat pada jalur hadis tersebut, dengan demikian kualitas sanad hadis ad-Darimi tentang kencing berdiri dinyatakan sahih.
\end{abstract}

Kata Kunci: Takhrij, Hadis, Kencing Berdiri.

\section{Pendahuluan}

Kencing berdiri merupakan permasalahan kontroversial di kalangan ahli fikih. Ada yang membolehkan dan ada juga yang melarang. Pendapat yang melarang tentu pendapat yang kuat, dan tampaknya lebih hati-hati. Karena lebih bersih dan lebih selamat dari najis. Dengan melarang kencing berdiri berarti pakaian yang dipakai lebih terasa meyakinkan karena tidak dikenai najis saat buang air kecil. Oleh karenanya, pendapat ini banyak diambil oleh ulama.

Di sisi lain, ada juga ulama yang berpendapat membolehkannya, asalkan aman dari percikan najis. Tentu selama dilakukan dengan benar, seperti dengan mengangkat pakaian, memilih tempat yang tidak keras sehingga najis tidak terpercik mengenai pakaian atau memilih toilet yang sudah memang terkondisikan seperti saat sekarang ini, maka pendapat kedua ini juga dapat diterima. Karena pada intinya, adalah bagaimana agar pakaian tetap terjaga dan tidak terkenai najis.

Bila dipulangkan kepada hadis Nabi sebagai sumber kedua hukum Islam, bagaimana sebenarnya status hadis-hadis Nabi mengenai kencing berdiri, apakah memang daif atau jangan-jangan adalah sahih. Penelitian ini hadir untuk menemukan jawaban atas permasalahan ini. 


\section{Pembahasan}

\section{A. Pengertian Takhrij Hadis}

Takhrij Hadis adalah menunjukkan letak sebuah hadis pada sumber aslinya dengan menyebutkan nama buku dan pengarangnya (perawi). Hal ini sebagaimana disimpulkan oleh Mahmud at-Tahhan dalam bukunya Usul atTakhrij wa Dirasatu al-Asanid, sebagai berikut:

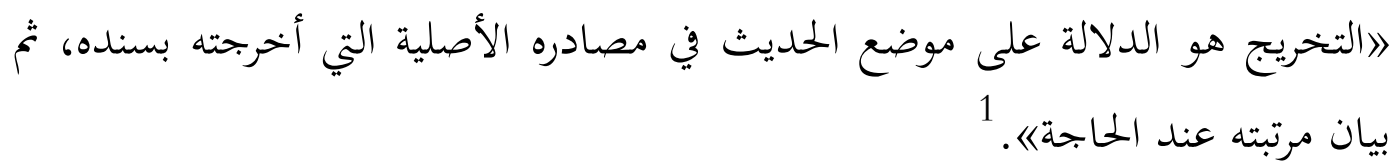

Takhrij ialah menunjukkan letak sebuah hadis pada sumber aslinya, di mana matan hadis tersebut diuraikan (oleh mu'allif-nya) secara lengkap dengan sanadnya, kemudian menjelaskan kualitasnya bila diperlukan.

Tahhan menegaskan bahwa yang dimaksud sumber asli Hadis adalah :

1. Kitab-kitab Sunah yang menghimpun Hadis-hadis Nabi saw., yang diperoleh oleh penulis kitab tersebut dari para gurunya, lengkap dengan sanadnya, sampai kepada Nabi saw., seperti al-Kutub as-Sittah, Muwatta' Malik dan Musnad Ahmad ibn Hanbal.

2. Kitab-kitab Sunah yang menghimpun beberapa koleksi buku Sunah sebelumnya, seperti buku karya al-Humaidiy yang berjudul al-Jam ` baina as-Sahihain, yang merupakan himpunan kitab Sahih al-Bukhari dan Sahih Muslim.

3. Kitab-kitab bidang lain, seperti tafsir, fikih dan tarikh. Di mana uraian pembahasan buku-buku tersebut memuat hadis-hadis Nabi saw., dengan catatan bahwa hadis-hadis tersebut harus dilengkapi dengan sanad yang diperoleh langsung dari guru-guru penulis, bukan hasil kutipan dari bukubuku lain.

Adapun buku-buku yang tidak termasuk sumber asli hadis adalah bukubuku Hadis yang menghimpun Hadis-hadis Nabi, tetapi Hadis-hadis tersebut diperoleh secara tidak langsung oleh penulis dari guru-gurunya. Buku-buku tersebut seperti kitab Bulugu al-Maram, karya ibn Hajar al-'Asqalaniy, al-Jami`

${ }^{1}$ Mahmud at-Tahhan, Usul at-Takhrij wa Dirasatu al-Asanid, (Riyad: Maktabah alMa`arif, 1996 M), cet. 3, h. 10. 
as-Sagir, karya Imam as-Suyuti, al-Arab`in an-Nawawiyah dan Riayadu asSalihin, karya Imam an-Nawawi. ${ }^{2}$

\section{B. Manfaat Takhrij Hadis}

Penguasaan tentang ilmu takhrij sangat penting, bahkan merupakan suatu kemestian bagi setiap yang berkecimpung di bidang ilmu-ilmu kesyariahan, khususnya yang menekuni bidang Hadis. Dengan mempelajari kaidah-kaidah dan metode takhrij, seseorang akan dapat mengetahui bagaimana cara untuk sampai kepada suatu Hadis di dalam sumber-sumbernya yang asli yang pertama kali disusun oleh para ulama pengkodifikasi Hadis.

Dengan mengetahui Hadis-hadis tersebut di dalam buku-buku sumber aslinya, maka akan diketahui sanad-sanadnya dengan lengkap. Hal ini akan memudahkan untuk melakukan penelitian atas kualitas hadis tersebut baik dari segi sanad maupun matannya.

\section{Metode Takhrij}

Di dalam melakukan takhrij, ada lima metode yang dapat dijadikan sebagai pedoman, yaitu:

1. Takhrij berdasarkan lapaz pertama dari teks Hadis. Salah satu kitab yang menggunakan metode ini adalah: al-Jami`u as-Sagir, karya Imam asSuyutiy (w. $911 \mathrm{H}$ ).

2. Takhrij melalui lafaz-lafaz (yang jarang) yang terdapat di dalam teks Hadis. Kitab yang terkenal menggunakan metode ini adalah kitab alMu `jam al-Mufahras, oleh A. J. Wensinck dan Muhammad Fu'ad `Abd alBaqi. Kitab ini mengumpulkan hadis-hadis yang terdapat di dalam Sembilan kitab induk Hadis.

3. Takhrij berdasarkan nama perawi pertama. Kitab-kitab yang disusun berdasarkan metode ini adalah kitab-kitab al-Atraf dan kitab-kitab alMusnad.

\footnotetext{
${ }^{2}$ Ibid.
} 
4. Takhrij menurut tema Hadis. Di antara kitab yang disusun berdasarkan metode ini adalah Miftah Kunuz as-Sunnah oleh Wensinck dan Nasbu arRayah, oleh az-Zaila`iy.

5. Takhrij menurut status/kualitas Hadis. Kitab-kitab yang disusun berdasarkan metode ini adalah: al-Azhar al-Mutanasirah fi al-Akhbar alMutawatirah, karangan Imam as-Suyuti, al-Marasil, oleh Abu Daud dan kitab-kitab sejenis lainnya.

Adapun metode takhrij yang akan digunakan dalam penelitian ini adalah metode takhrij yang kedua, yaitu takhrij berdasarkan lafaz-lafaz (yang jarang) yang terdapat di dalam teks hadis kencing berdiri. Lebih spesifik, penulis akan mencoba menelusuri dengan menggunakan lapaz-lapaz seperti سباطة قوم dan بال قائما.

\section{Kriteria Kesahihan Hadis}

Ulama Hadis, sebagaimana disebutkan oleh Mahmud at-Tahhan dalam kitabnya Usul at-Takhrij, sepakat bahwa kriteria kesahihan Hadis adalah lima macam. Apabila salah satu dari kriteria tersebut tidak terpenuhi maka nilai hadis tersebut dinyatakan tidak sahih. Keriteria kesahihan hadis dimaksud adalah sebagai berikut:

1. Semua perawinya adil,

2. Semua perawinya dabit.

3. Sanadnya bersambung-sambung.

4. Sanad dan matan-nya terbebas dari kejanggalan.

5. Sanad dan matan-nya terbebas dari ilat. ${ }^{3}$

Dari lima kriteria kesahihan hadis sebagaimana disebutkan di atas dapat diklasifikasikan menjadi dua unsur. Tiga unsur pertama hanya berhubungan dengan sanad, sedangkan dua unsur terahir berhubungan dengan sanad dan matan. Jika sebuah hadis memenuhi seluruh unsur tersebut, maka hadis itu dinilai sahih dan dapat dijadikan hujah, sebaliknya jika salah satu unsurnya tidak terpenuhi, maka hadisnya ditolak.

\footnotetext{
${ }^{3}$ Ibid., h. 189.
} 
Penelitian ini dilakukan untuk mengetahui apakah teori kesahihan hadis tersebut terpenuhi pada hadis yang sedang diteliti, yaitu hadis tentang kencing berdiri. Pembahasan berikut adalah tahapan praktis yang penulis lakukan untuk penelitian tersebut.

\section{E. Kritik Sanad Hadis Kencing Berdiri}

\section{Identifikasi Hadis}

Dalam melakukan identifikasi hadis yang diteliti, rujukan utama yang dipergunakan adalah kitab-kitab Hadis yang sembilan. Penelusuran hadis dilakukan berdasarkan pada kata-kata yang terdapat di dalam matan hadis, dengan mempergunakan metode kedua.

\section{Klasifikasi Hadis}

Dalam melakukan klasifikasi hadis yang akan diteliti, peneliti menetapkan kriteria tertentu, di antaranya:

a. Hadis yang dipilih adalah hadis-hadis yang berkaitan langsung dengan pokok masalah penelitian, yaitu tentang kencing berdiri.

b. Hadis-hadis tersebut akan diperhatikan dalam penelitian ini, dan dibatasi pada salah satu hadis yang memiliki sanad yang belum disepakati oleh jumhur ulama hadis tentang kesahihannya, dan satu hadis yang telah disepakati kesahihan sanadnya.

\section{Takhrij Hadis}

Hadis-hadis yang memuat tentang kencing berdiri dapat ditelusuri dengan lima metode takhrij yang ada. Dalam penelitian ini akan digunakan metode takhrij berdasarkan pada kata-kata yang terdapat pada matan Hadis, yaitu metode kedua, dengan mempergunakan kitab al-Mu jam al-Mufahras, dengan menelusuri kosa kata Fa Bala, yang berasal dari kata bala, maka ditemukan dua hadis tentang kencing berdiri dengan redaksi dan kandungan matan yang bervariasi, yaitu: 
1) Riwayat Huzaifah di dalam Sahih al-Bukhari, dengan teks sebagai berikut:

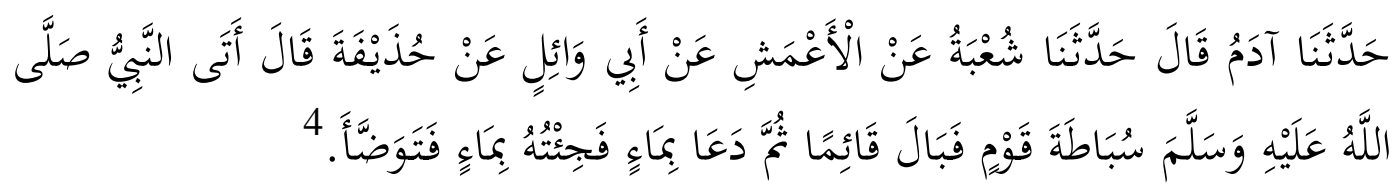

Imam al-Bukhari berkata: Adam menceritakan kepada kami, Syu’bah menceritakan kepada kami dari al-A ‘masy, dari Abi Wa'il, dari Huzaifah, ia berkata, "Nabi saw., mendatangi tempat pembuangan sampah suatu kaum, lalu beliau kencing sambil berdiri, kemudian beliau meminta air kepadaku, setelah itu beliau berwuduk (H.R. al-Bukhari).

2) Riwayat Imam Muslim di dalam Sahih Muslim dengan redaksi sebagai berikut:

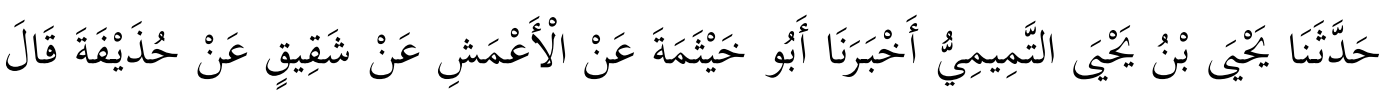

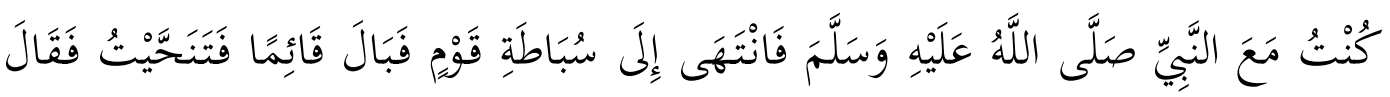

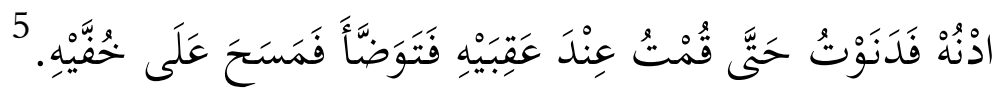

3) Riwayat Imam at-Turmuzi di dalam kitab Sunan-nya dengan redaksi sebagai berikut:

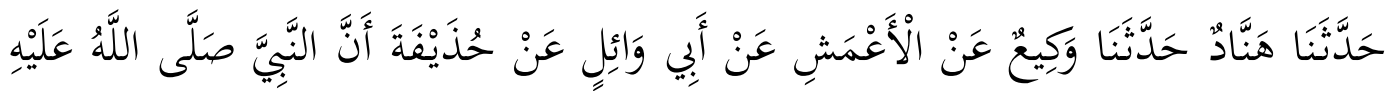

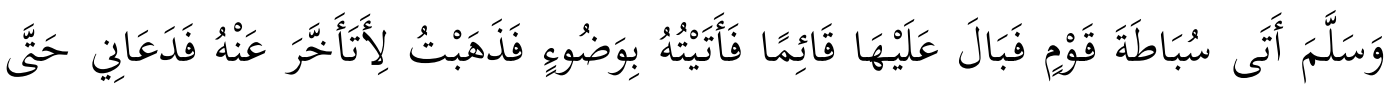



4) Riwayat an-Nasa'i di dalam kitab Sunan-nya dengan redaksi sebagai berikut:

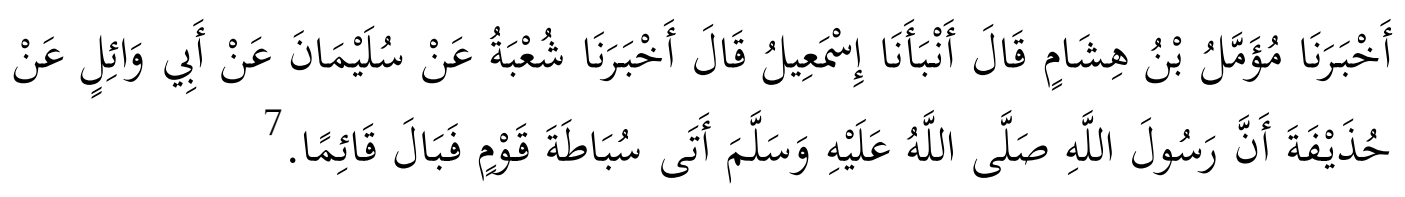

${ }^{4} \mathrm{Abu}$ `Abdillah Muhammad ibn Isma`il al-Bukhari, Sahih al-Bukhari, (t.t.p. :Dar Tauq an-Najat, $1422 \mathrm{H})$, cet. 1. h. 54. h. 228 .

${ }^{5}$ Muslim Ibn al-Hajjaj, Sahih Muslim, (Beirut: Dar Ihya’ at-Turas al-'Arabi: t.t.t.), jilid. 1,

${ }^{6}$ Muhammad Ibn 'Isa at-Tirmizi, Sunan at-Tirmizi, (Beirut: Dar al-Garb al-Islamiy, 1998 M), jilid. 1, h. 64 .

${ }^{7} \mathrm{Abu}$ 'Abdirrahman Ahmad Ibn Syu'aib an-Nasa'i, Sunan an-Nasa'i, (Halb: Maktab alMatbu`at al-Islamiyah, 1986 M), jilid. 1, h. 25. 
5) Riwayat Abu Daud di dalam kitab Sunan-nya dengan redaksi sebagai berikut:

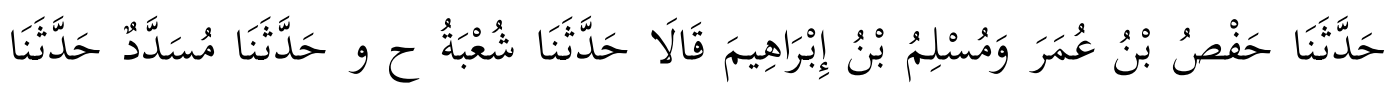

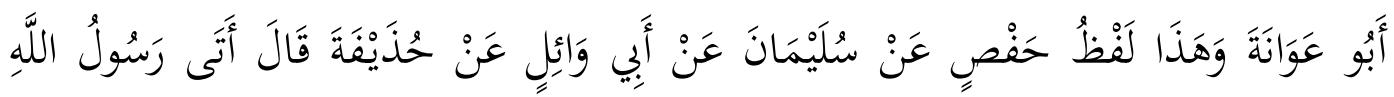

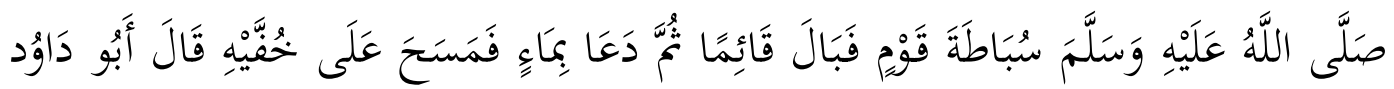

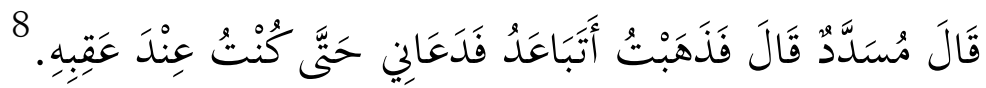

6) Riwayat Imam Ibnu Majah di dalam kitab Sunan-nya dengan redaksi sebagai berikut:

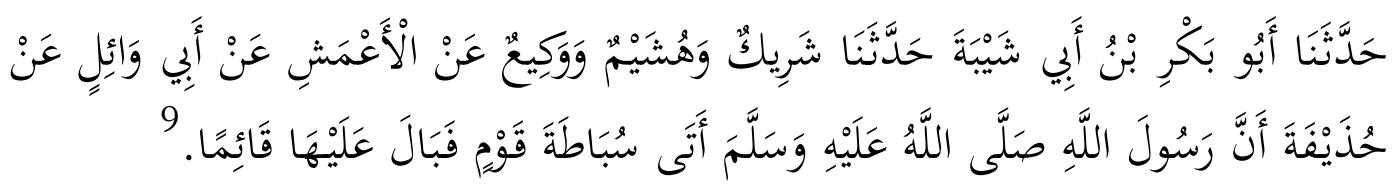

7) Riwayat Imam Ahmad di dalam kitab Musnad-nya dengan redaksi sebagai berikut:

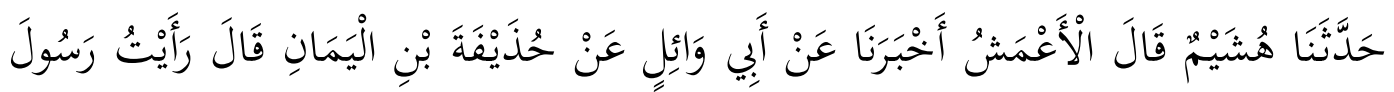

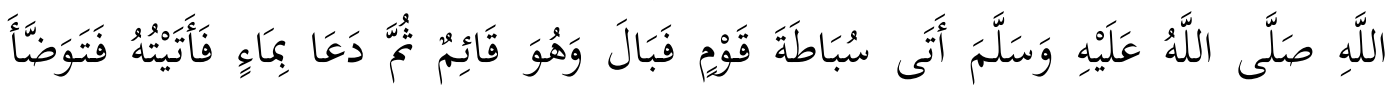
10.

8) Riwayat Imam ad-Darimi di dalam kitab Sunan-nya dengan redaksi sebagai berikut:

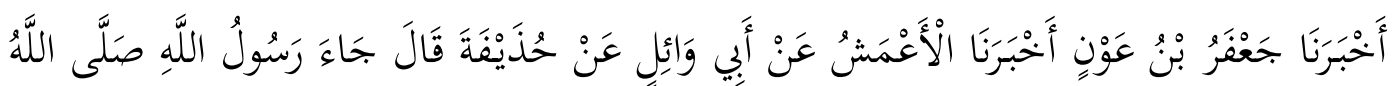

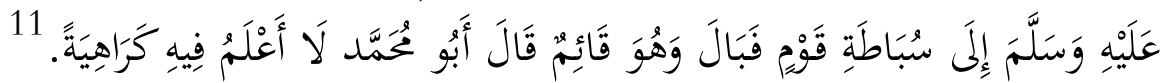

${ }^{8}$ Abu Daud Sulaiman Ibn al-Ays`asy as-Sijistiayani, Sunan Abi Daud, (Beirut: alMaktabah al-'Asriyah, t.t.t.), jilid. 1, h. 6.

${ }^{9}$ Ibn Majah Abu 'Abdillah, Sunan Ibn Majah, (t.t.p.: Dar Ihya' al-Kutub al-'Arabiyah, t.t.), jilid. 1, h. 111 .

${ }^{10} \mathrm{Abu}$ 'Abdillah Ahmad Ibn Muhammad Ibn Hanbal asy-Syaibani, Musnad Ahmad, (Riyad: Muassasah ar-Risalah, jilid. 38, 2001 M), h. 227.

${ }^{11}$ Abu Muhammad 'Abdullah Ibn 'Abdirrahman ad-Darimi as-Samarqandi, Sunan adDarimi, (Riyad: Dar al-Mugni Li an-Nasyr, 2000 M), jilid. 1, h. 529. 


\section{I tibar as-Sanad}

Hadis-hadis tentang kencing berdiri di atas, keseluruhannya berasal dari Sahabat Huzaifah ${ }^{12}$. I tibar dilakukan dengan cara mengkombinasikan antara sanad yang satu dengan sanad yang lainnya, sehingga terlihat dengan jelas jalur sanad yang diteliti, seluruh para perawinya dan metode periwayatannya.

Dengan $i$ tibar, juga dapat diketahui apakah ada unsur mutabi atau syahid pada hadis tersebut atau tidak ada. Hasil i tibar dari sanad hadis tentang kencing berdiri dapat dilihat pada skema berikut:

Skema sanad hadis kencing berdiri:

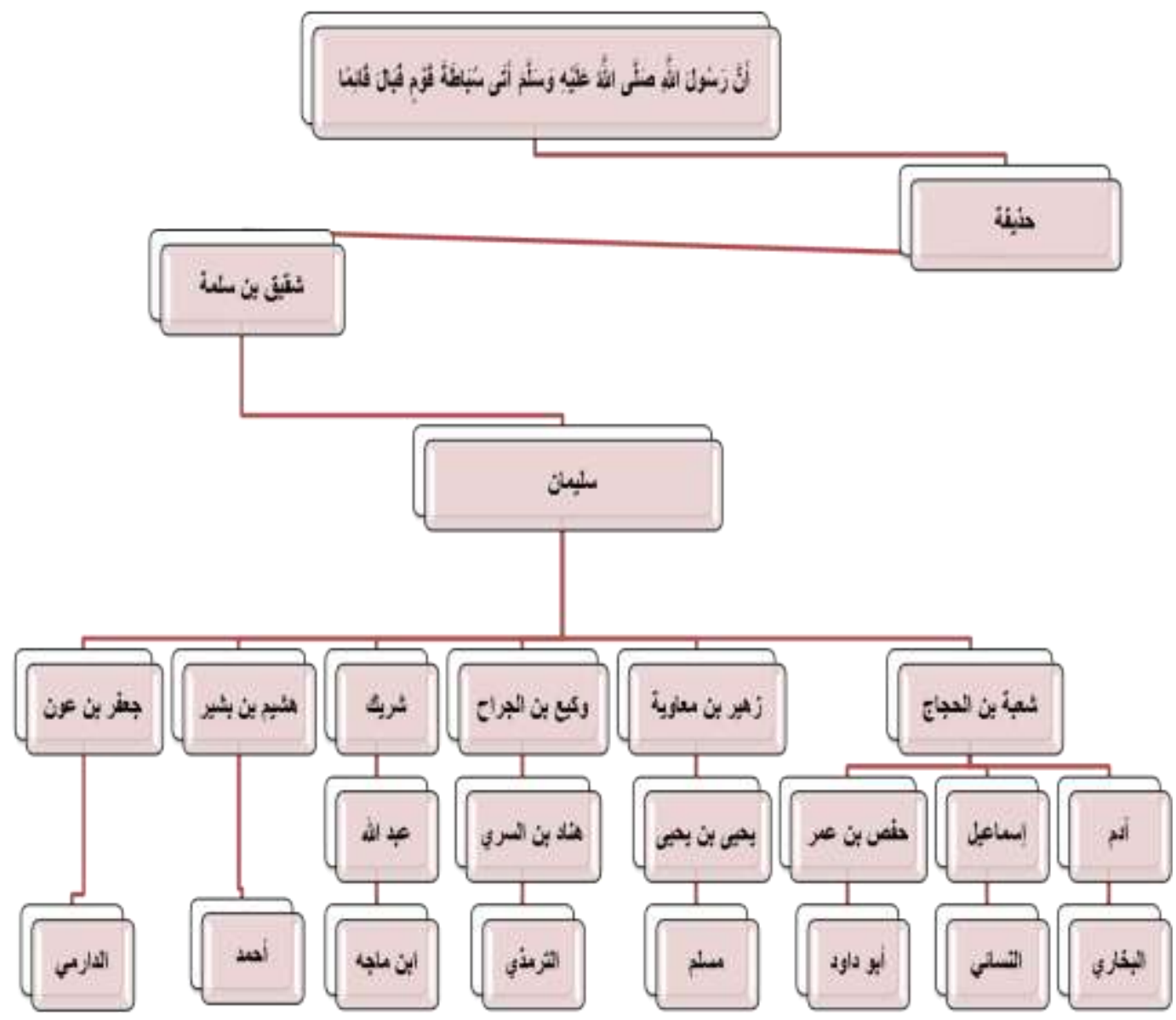

${ }^{12}$ Terdapat jalur-jalur lain yang tidak termuat secara keseluruhan dalam kesempatan ini. Penulis, karena beberapa pertimbangan, hanya memuat sebagian jalur sanad saja untuk keperluan i'tibar. 


\section{Penelitian terhadap kesiqahan para Perawi (Keadilan dan Kedabitan)}

Dalam melakukan kritik terhadap sanad hadis yang sedang diteliti, yaitu hadis-hadis tentang kecing berdiri maka acuan yang dipergunakan adalah sejumlah prinsip dan kriteria yang telah ditetapkan dalam ilmu hadis dan usul takhrij wa dirasatu al-asanid.

Karena pertimbangan waktu, maka penelitian ini hanya difokuskan pada sanad hadis yang ditakhrij oleh Imam ad-Darimi. Pemilihan objek bahasan dilakukan secara acak, tanpa melalui seleksi atau pertimbangan terlebih dahulu. Karena, inti dari penelitian ini sesungguhnya hanya ditujukan untuk bahan latihan pada matakuliah usul takhrij, bukan untuk memberikan penilaian secara utuh terhadap hadis-hadis kencing berdiri. Karena yang demikian menuntut penelusuran yang lebih serius, mendalam dan komprehensif, sehingga dapat diketahui apakah hadis tersebut memiliki ilat atau kejanggalan.

\section{a. Biografi Ruwat dan Kritik Sanad}

Setelah menemukan hadis yang akan diteliti, baik secara sanad maupun matannya, maka langkah berikutnya adalah mengidentifikasi nama-nama perawi yang terdapat dalam sanad. Nama-nama tersebut ditelusuri melalui kitab-kitab tarajim ar-ruwat/kutub ar-rijal. Melalui penelusuran ini peneliti akan mengetahui banyak inforamsi tentang perawi, baik nama lengkap, kuniah, masa hidup, guruguru dan murid-muridnya. Adapun hadis yang akan diteliti pada kesempatan ini adalah sebagai berikut:

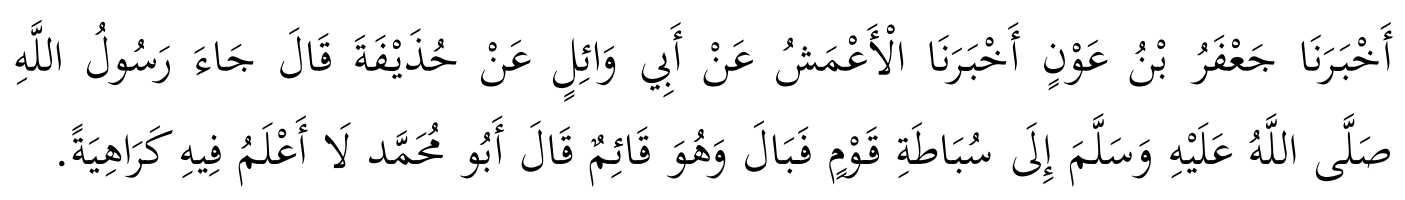

Sanad hadis di atas termasuk Imam ad-Darimi terdiri atas lima orang perawi, mereka adalah:

\begin{tabular}{|c|c|c|}
\hline No & Nama Perawi & Sigah at-Tahammul \\
\hline 1 & Ad-Darimi & أخبرنا \\
\hline 2 & Ja'far Bin 'Aun & أخبرنا \\
\hline 3 & Sulaiman Al-A'masy & عن \\
\hline 4 & Abi Wa'il Syaqiq Ibn Salamah & عن \\
\hline 5 & Huzaifah Ibn al-Yaman & قال \\
\hline
\end{tabular}


Untuk meneliti keadilan dan kedabitan (syarat hadis sahih pertama dan kedua) para perawi di atas maka penulis akan menelusuri buku-buku biografi para perawi hadis (tarajim ar-ruwat), selanjutnya melalui biografi tersebut akan diperhatikan pernyataan para kritikus Hadis (ulama al-jarh wa at-ta`dil) tentang diri mereka.

\section{1) Ad-Darimi}

a) Nama lengkapnya adalah 'Abdurrahman Ibn 'Abdirrahman Ibn Fadl Ibn Bahram Ibn 'Abd as-Samad. Kuniyahnya adalah Abu Muhammad.

b) Masa hidupnya. Dia lahir pada tahun wafatnya Imam Ibn alMubarak, yaitu pada tahun 181 H, di kota Samarqand.

c) Guru-gurunya. Di antara guru-gurunya adalah Yazid Ibn Harun, Ya'la Ibn 'Ubaid, Ja'far Ibn 'Aun, Basyar Ibn 'Umar azZahrani, Abu 'Ali 'Ubaidillah Ibn 'Abd al-Majid al-Hanafiy dan Abu Bakar 'Abd al-Kabir.

d) Murid-muridnya. Di antaranya al-Imam Muslim, Abu Daud, atTirmizi, 'Abd Ibn Humaid, Raja' Ibn Marja', Hasan Ibn asSabbah al-Bazzar, Muhammad Ibn Basyar Bandar dan Muhammad Ibn Yahya.

e) Pernyataan para kritikus Hadis (ulama al-jarh wa at-ta`dil) tentang diri ad-Darimi:

I. Ahmad Ibn Hanbal berkata, "ad-Darimi adalah Imam".

II. Muhammad Ibn 'Abdillah Ibn Numair berkata, “'Abdullah Ibn 'Abdurrahman ad-Darimi mengalahkan kami dalam hal hafalan dan sifat waraknya".

III. Abu Hatim ar-Razi berkata, "'Abullah Ibn 'Abdurrahman (ad-Darimi) adalah orang yang paling kokoh di antara mereka". Pada kesempatan lain ia mengatakan, "Imam ahli Hadis di zamannya, dan siqah, saduq".

IV. Ad-Daruqutni mengatakan, "Beliau adalah seorang yang siqah lagi masyhur". 
V. Imam al-Hakim mengatakan, "Ia termasuk seorang hafiz yang cemerlang di bidang Hadis".

VI. Az-Zahabi mengatakan, "beliau adalah seorang al-Hafiz dan al-Imam".

\section{2) Ja`far Ibn 'Aun}

a) Nama lengkapnya adalah Ja far Ibn 'Aun Ibn Ja'far Ibn 'Amar Ibn Hurais al-Makhzumiy al-Kufiy.

b) Masa hidupnya. Beliau lahir pada tahun $120 \mathrm{H}$ menurut satu pendapat, sementara pendapat lain pada tahun 130 H. Ibn Hajar mengurutkan beliau pada pringkat kesembilan, yang menunjukkan bahwa beliau adalah salah seorang pengikut tabiin yang terkecil. Wafatnya yaitu pada tahun $206 \mathrm{H}$ menurut satu versi, sementara menurut versi lain pada tahun $207 \mathrm{H}^{13}$

c) Guru-gurunya. Di antara guru-gurunya adalah Ibrahim Ibn Muslim al-Hijri, al-Ajlah Ibn 'Abdillah al-Kindi, Basyir Ibn alMuhajir, Sufyan as-Sauri, Sulaiman al-A'masy , dll.

d) Murid-muridnya. Di antaranya Ishak Ibn Rahawaih, Ibrahim Ibn Abdillah al-‘Absi al-Qassar, Ahmad Ibn Muhammad Ibn Hanbal, Ja`far Ibn Muhammad Ibn 'Imran as-Sa`labiy, Abu Khaisamah Zuhair Ibn Harb, ‘Ali Ibn ‘Abdullah al-Madiniy, dll.

e) Pernyataan para kritikus Hadis (ulama al-jarh wa at-ta`dil) tentang diri Ja` far Ibn 'Aun:

I. Ibn Hajar berkata, "saduq".

II. Muhammad Ibn 'Abdilwahhab al-Farra' menceritakan, "Ahmad Ibn Hanbal bertanya kepadaku: 'hendak kemana engkau pergi?', ke Kufah, jawabku. Temuilah di sana Ja far Ibn ‘Aun, balas Ahmad Ibn Hanbal.”

III. Yahya Ibn Ma in berkata, "ia adalah seorang yang siqah".

IV. Abu Hatim ar-Razi, "saduq".

${ }^{13}$ Ahmad Ibn 'Ali Ibn Hajar al-'Asqalaniy, Taqrib at-Tahzib, (Riyad: Dar al-'Asimah, 1416 H), cet. 1, h. 414. 
3) Sulaiman Al-A'masy

a) Nama lengkapnya adalah Sulaiman Ibn Mahran al-Kahiliy alKufiy al-A`masy Abu Muhammad.

b) Masa hidupnya. Beliau lahir pada awal tahun $61 \mathrm{H}^{14}$ dan wafat pada tahun $148 \mathrm{H}^{15}$. Menurut keterangan Ibn Hajar beliau termasuk pada generasi kelima, yaitu min sigar at-tabi in (tokoh junior dari kalangan tabiin).

c) Guru-gurunya. Di antara guru-gurunya adalah Aban Ibn Abi 'Ayyasy, Ibrahim at-Tamimi, Ibrahim an-Nakha`i, Sa`id Ibn Jubair, Abi Wa'il Syaqiq Ibn Salamah al-Asadiy, 'Amir asySya biy, Malik Ibn al-Haris, dll.

d) Murid-muridnya. Di antaranya Aban Ibn Tagallub, Isra'il Ibn Yunus, Ishaq Ibn Yusuf al-Azraq, Ja’far Ibn 'Aun, Isma`il Ibn Zakaria, dll.

e) Pernyataan para kritikus Hadis (ulama al-jarh wa at-ta`dil) tentang diri Sulaiman al-A`masy:

I. Ibn Hajar berkata, "siqah, hafiz, 'arif bi al-qira'ah, wari', akan tetapi dia seorang mudallis". ${ }^{16}$

II. Yahya Ibn Ma`in mengatakan, "Sulaiman Ibn Mahran adalah seorang yang siqah".

III. Abi Hatim ar-Razi mengatakan, "telah menceritakan kepada kami 'Abdurrahman bahwa ia mendengar ayahnya berkata: al-A`masy adalah seorang siqah yang riwayat hadisnya dapat dijadikan hujah". ${ }^{17}$

IV. Abu Zur’ah berkata, “al-A 'masy adalah seorang imam”.

V. 'Amar Ibn 'Ali berkata, "Amar bagaikan sebuah Mushaf sebab kejujurannya".

\footnotetext{
${ }^{14}$ Ibn Hajar al-'Asqalaniy, Taqrib at-Tahzib, h. 200.

15 Syamsuddin Muhammad Ibn Ahmad az-Zahabiy, Mizan al-I tidal, (Beirut: Dar alKutub al-'Ilmiyah, 2008 H), cet. 2, h. 315-316.

${ }^{16}$ Ibn Hajar al-'Asqalaniy, Taqrib at-Tahzib, h. 414.

${ }^{17}$ Abu Muhammad 'Abdurrahman ar-Razi Ibn Abi Hatim, al-Jarh wa at-Ta dil, (Beirut:
} Dar Ihya’ at-Turas al-'Arabi, 1952 H, jilid IV), cet. 1, h. 146. 
VI. Ahmad Ibn 'Abdullah al-'Ajli berkata, " beliau adalah seorang yang siqah dan tetap hafalannya dalam bidang hadis, di samping itu ia juga merupakan pakar Hadis di negeri Kufah di zamannya”.

VII. Waki’ berkata, “ umur A 'masy hampir mendekati 70 tahun, beliau tidak pernah tertinggal sekali pun dari takbir yang pertama pada salat berjemaah".

VIII. Imam an-Nasa'i berkata, “ beliau adalah seorang yang siqah lagi sabat". ${ }^{18}$

\section{4) Abi Wa'il Syaqiq Ibn Salamah}

a) Nama lengkapnya adalah Syaqiq Ibn Salamah al-Asadiy, Abu Wa'il al-Kufi.

b) Masa hidupnya. Sejauh yang penulis telusuri belum ditemukan tahun lahirnya, akan tetapi sebagaimana keterangan Ibnu Hajar, beliau hidup selama 100 tahun dan wafat pada masa pemerintahan Umar Ibn 'Abdil 'Aziz, ${ }^{19}$ sedangkan menurut keterangan Imam az-Zahabi beliau wafa pada tahun $82 \mathrm{H}^{20}$. az-Zahabi juga menjelaskan bahwa beliau berstatus mukhadram dan pernah hidup di masa jahiliah selama tujuh tahun. ${ }^{21}$ Imam Ibn Hajar al'Asqalani mengurutkan generasi beliau pada pringkat kedua yang menunjukkan bahwa beliau min kibar at-tabi in (termasuk tokoh senior tabiin). ${ }^{22}$

c) Guru-gurunya. Di antara guru-gurunya adalah Umar, 'Ali, Ibn Mas`ud, Jarir Ibn 'Abdullah al-Bajli, Abu Musa al-Asy`ari, alMugirah Ibn Syu`bah, dll.

${ }^{18}$ Yusuf Ibn 'Abdirrahman Abu al-Hajjaj Jamaluddin al-Mizzi, Tahzib al-Kamal Fi Asma 'i ar-Rijal, (Beirut: Mu'assasah ar-Risalah, 1980 M, jilid XII), cet. 1, h. 76.

${ }^{19}$ Ibn Hajar, Taqrib, h. 439.

20 Syamsuddin Muhammad Ibn Ahmad az-Zahabiy, al-Kasyif, (Jeddah: Mu'assasah 'Ulum al-Qur'an, 1992 H), jilid. 1, cet. 1, h. 489.

${ }^{21}$ Ibid.

${ }^{22}$ Ibn Hajar, Taqrib, h. 439. 
d) Murid-muridnya. Antara lain adalah Mansur, Sulaiman alA`masy, 'Asim, dll.

e) Pernyataan para kritikus Hadis (ulama al-jarh wa at-ta`dil) tentang diri Wa'il Syaqiq Ibn Salamah:

I. Ibn Hajar, "siqah".

II. Az-Zahabi, "Min al- 'Ulama' al- 'Amilin".

III. Waki mengatakan, "Abu Wa'il Siqah". ${ }^{23}$

IV. Yahya Ibn Ma'in berkata, “ Abu Wa'il Siqah tidak dipertanyakan lagi tentang beliau". ${ }^{24}$

\section{5) Huzaifah Ibn al-Yaman}

a) Nama lengkapnya adalah Huzaifah Ibn al-Yaman Abu 'Abdillah al-'Absi.

b) Masa hidupnya. Beliau adalah sahabat terdekat Nabi saw., dari kalangan al-Muhajirin, pemegang rahasia-rahasia beliau tentang orang-orang munafik. Wafat pada hari ke 40 setelah terbunuhnya 'Usman Ibn 'Affan, tepatnya tahun $36 \mathrm{H}$.

c) Guru-gurunya. Beliau menerima Hadis langsung dari Rasulullah saw., dan Umar Ibn al-Khattab.

d) Murid-muridnya. Antara lain adalah al-Aswad Ibn Yazid anNakha`i, Jabi Ibn 'Abdillah, Zaid Ibn Wahab al-Juhani, Abu Wa'il Syaqiq Ibn Salamah al-Asadiy, dll.

e) Pernyataan para kritikus Hadis (ulama al-jarh wa at-ta`dil) tentang diri Wa'il Syaqiq Ibn Salamah:

I. Ibn Hajar, "Sahabi”.

II. Az-Zahabi, "Sahabi, Sahib as-Sirr". ${ }^{25}$

${ }^{23}$ Ibn Abi Hatim ar-Razi, al-Jarh wa at-Ta`dil, jilid. 4, h. 371.

${ }^{24}$ Ibid.

${ }^{25}$ al-Mizzi, Tahzib al-Kamal, jilid V, h. 496. 


\section{b. Kesimpulan Penilaian Ulama al-Jarh dan at-Ta`dil tentang Rijal al-}

\section{Isnad}

Sebelum memberikan penilaian akhir terhadap sanad hadis yang ditakhrij oleh Imam ad-Darimi tentang kencing berdiri di atas, ada baiknya terlebih dahulu disajikan kembali pernyataan ulama al-jarh dan at-ta`dil dalam bentuk tabel sebagaimana berikut:

\begin{tabular}{|c|c|c|c|}
\hline Nama Perawi & $\begin{array}{c}\text { Ulama Jarh- } \\
\text { Ta'dil } \\
\end{array}$ & $\begin{array}{c}\text { Pernyataan Jarh atau } \\
\text { Ta`Dil } \\
\end{array}$ & Kesimpulan \\
\hline \multirow{3}{*}{ Ad-Darimi } & $\begin{array}{l}\text { Abu Hatim ar- } \\
\text { Razi }\end{array}$ & $\begin{array}{l}\text { Imam ahli } \begin{array}{l}\text { Hadis } \\
\text { zamannya, } \\
\text { saduq }\end{array} \\
\text { siqah }\end{array}$ & \multirow{3}{*}{ Siqah } \\
\hline & Ad-Daruqutni & $\begin{array}{l}\text { Beliau adalah seorang yang } \\
\text { siqah lagi masyhur }\end{array}$ & \\
\hline & Az-Zahabi & $\begin{array}{l}\text { Beliau adalah seorang al- } \\
\text { Hafiz dan al-Imam }\end{array}$ & \\
\hline \multirow{3}{*}{$\begin{array}{l}\text { Ja`far Bin } \\
\text { 'Aun }\end{array}$} & Ibn Hajar & saduq & \multirow{3}{*}{ Siqah } \\
\hline & Yahya Ibn Ma`in & $\begin{array}{l}\text { Ia adalah seorang yang } \\
\text { siqah }\end{array}$ & \\
\hline & Abu Hatim ar-Razi & saduq & \\
\hline \multirow{3}{*}{$\begin{array}{l}\text { Sulaiman Al- } \\
\text { A'masy }\end{array}$} & Ibn Hajar & $\begin{array}{l}\text { Siqah, hafiz, 'arif bi al- } \\
\text { qira'ah, wari', akan tetapi } \\
\text { mudallis }\end{array}$ & \multirow{3}{*}{$\begin{array}{l}\text { Siqah, } \\
\text { Mudallis }\end{array}$} \\
\hline & Yahya Ibn Ma`in & $\begin{array}{l}\text { Sulaiman Ibn Mahran } \\
\text { adalah seorang yang siqah }\end{array}$ & \\
\hline & Imam an-Nasa'i & $\begin{array}{l}\text { Beliau seorang yang siqah } \\
\text { lagi sabat }\end{array}$ & \\
\hline \multirow{3}{*}{$\begin{array}{l}\text { Abi Wa'il } \\
\text { Syaqiq Ibn } \\
\text { Salamah }\end{array}$} & Ibn Hajar & siqah & \multirow[b]{3}{*}{ Siqah } \\
\hline & Az-Zahabi & Min al-'Ulama' al- 'Amilin & \\
\hline & Yahya Ibn Ma`in & $\begin{array}{l}\text { Abu Wa'il Siqah tidak } \\
\text { dipertanyakan lagi tentang } \\
\text { dirinya }\end{array}$ & \\
\hline \multirow{2}{*}{$\begin{array}{l}\text { Huzaifah Ibn } \\
\text { al-Yaman }\end{array}$} & Ibn Hajar & $\begin{array}{l}\text { Sahabiyun Jalil Min as- } \\
\text { Sabiqin }\end{array}$ & \multirow[t]{2}{*}{ Pasti Siqah } \\
\hline & Az-Zahabi & Sahabi, Sahib as-Sirr & \\
\hline
\end{tabular}

Dari tabel di atas dapat dilihat bahwa semua jalur perawi hadis tentang kencing berdiri yang ditakhrij oleh Imam ad-Darimi adalah siqah. Ini berarti bahwa seluruh perawinya bersifat adil dan dabit, sehingga dapat disimpulkan bahwa riwayat mereka tentang kencing berdiri di atas dapat dipercaya. Adapun 
catatan Imam Ibn Hajar tentang diri al-A'masy, tidak bersentuhan langsung dengan kualitas kepribadian beliau (keadilan dan kedabitannya), melainkan berhubungan dengan masalah penerimaan hadis dari rawi sebelumnya atau tidak, dan ini berhubungan dengan kebersambungan sanad atau tidak, bukan masalah keadilan dan kedabitan beliau. Dengan demikian, dapat disimpulkan bahwa seluruh sanad ad-Darimi dapat dipercaya.

\section{c. Penelitian terhadap Kebersambungan Sanad Hadis ad-Darimi}

Setelah meneliti tentang syarat pertama dan kedua tentang kriteria hadis sahih, maka langkah berikutnya adalah meneliti tentang kebersambungan sanad. Untuk lebih jelasnya penulis akan memuat kembali tabel sanad riwayat ad-Darimi sebagaimana telah disinggung sebelumnya, yaitu:

\begin{tabular}{|c|c|c|c|}
\hline No & Nama Perawi & Sigah at-Tahammul & Keterangan \\
\hline 1 & Ad-Darimi & أخبرنا & Sama' \\
\hline 2 & Ja'far Bin 'Aun & أخبرنا & Sama' \\
\hline 3 & Sulaiman Al-A'masy & عن & Mu`an`an \\
\hline 4 & Abi Wa'il Syaqiq Ibn Salamah & عن & Mu`an`an \\
\hline 5 & Huzaifah Ibn al-Yaman & 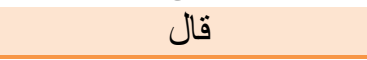 & Qala \\
\hline
\end{tabular}

Berdasarkan tabel di atas, maka alfaz at-tahammul wa al-ada' dan hukum penggunaannya dapat diuraikan sebagai berikut:

1. Sanad pertama dan kedua yaitu Imam ad-Darimi dan Ja'far Ibn 'Aun, keduanya menggunakan metode periwayatan yang sama yaitu: “أخبرنا “. Penggunaan sigah al-ada' semacam ini menunjukkan kebersambungan sanad di antara mereka. Dengan demikian dapat disimpulkan bahwa sanad antara ad-Darimi dengan gurunya Ja ' far Ibn 'Aun, begitu juga sanad Ja ’ar Ibn 'Aun dengan gurunya Sulaiman al-A`masy dinyatakan bersambung.

2. Sanad ke empat adalah Abi Wa'il Syaqiq Ibn Salamah, beliau menggunakan metode ada' 'an. Penggunaan metode seperti ini tidak menunjukkan secara jelas kebersambungan sanadnya, sehingga tidak dapat dipastikan apakah bersambung atau tidak. Oleh karena itu para ulama berbeda pendapat tentang hukum riwayat perawi yang mu`an`an. Mahmud at-Tahhan dalam bukunya Taisir Mustalah al-Hadis menyebutkan bahwa 
riwayat mu`an `an dikategorikan muttasil dengan dua syarat ${ }^{26}$, yaitu: 1 . Perawinya tidak mudallis, 2. Ada kemungkinan terjadinya pertemuan antara kedua perawi. Berdasarkan keterangan ulama al-jarh dan ta`dil tentang diri Abu Wa'il bahwa mereka sepakat mengatakan beliau adalah siqah, tidak seorang pun yang menyatakan bahwa dirinya sebagai mudallis. Selain itu, beliau juga tercatat di antara kelompok murid-murid Huzaifah Ibn al-Yaman. Karena beliau bukanlah seorang mudallis dan beliau juga tercatat sebagai murid sahabat Huzaifah, maka dapat dinyatakan bahwa sanadnya bersambung.

3. Sanad kelima adalah sahabat Huzaifah Ibn al-Yaman, beliau adalah seorang sahabat. Seorang sahabat sudah dapat dipastikan siqah dan bertemu dengan Nabi saw.

4. Sanad ke empat adalah Sulaiman al-A`masy. Sigah at-tahammul yang digunakan oleh beliau adalah 'an, yang menunjukkan riwayatnya adalah mu`an`an. Riwayah al-mu`an`an sebagaimana telah dikemukakan di awal, tidak dapat diterima kecuali dengan dua syarat yaitu: 1. Perawinya tidak mudallis, kemudian, 2. ada kemungkinan terjadinya pertemuan antara kedua perawi.

Diri al-A'masy sebagaimana yang dijelaskan oleh Ibn Hajar adalah seorang mudallis. Akan tetapi ulama menjelaskan seperti Imam az-Zahabi di dalam bukunya Mizan al-I'tidal, sebagai berikut:

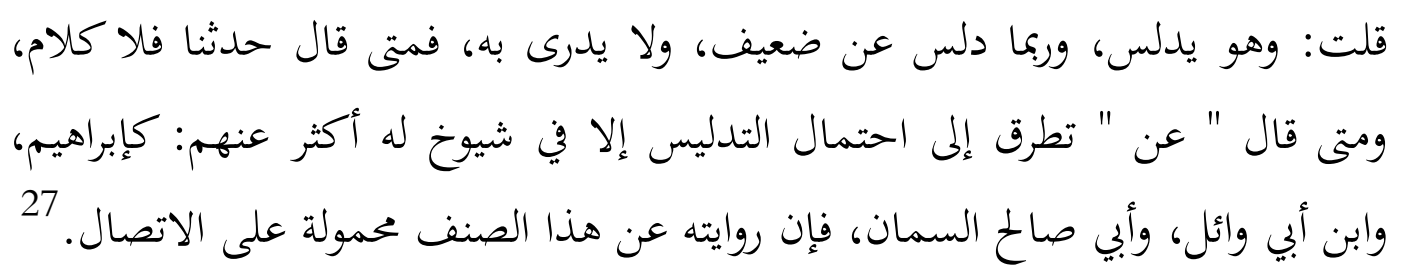

Saya (az-Zahabi) katakan, "Beliau seorang yang mau melakukan tadlis, terkadang mentadlis dari perawi yang daif tanpa beliau sadari. Bila metode periwayatan yang beliau gunakan adalah seperti حدثن maka tidak ada masalah, akan tetapi jika lambang periwayatan yang digunakan adalah "

${ }^{26}$ Kedua syarat tersebut merupakan kesepakatan mayoritas ulama Hadis, fikih dan usul fikih. Adapun syarat lain seperti subut al-liqa, tulu as-suhbah dan ma'rifatuhu bi ar-riwayati 'anhu, masih diperselisihkan di antara ulama. Lihat Mahmud at-Tahhan, Taisir Mustalah al-Hadis, (Riyad: Maktaba al-Ma`arif, 2004 M), cet. 10, h. 108.

${ }^{27}$ az-Zahabiy, Mizan al-I`tidal, (Beirut: Dar al-Ma`rifah, jilid. II, 1963 M), cet. 1, h. 224. 
" maka boleh jadi riwayatnya mudallis, kecuali dari guru-guru beliau yang banyak meriwayatkan hadis dari mereka, seperti Ibrahim, Ibn Abi Wa'il, Abi Salih as-Siman. Riwayat beliau dari salah seorang dari mereka besar kemungkinan adalah muttasil.

Dengan membaca biografi kedua perawi di atas dapat dipastikan bahwa antara keduanya terdapat hubungan guru dengan murid. Dengan demikian dapat disimpulkan bahwa sanad al-A'masy dari gurunya Ibn Abi Wa'il adalah bersambung.

Dari beberapa kesimpulan di atas maka kesimpulan akhir tentang sanad hadis yang ditakhrij ad-Darimi tentang kencing berdiri di atas dinyatakan sahih. ${ }^{28}$

\section{d. Penelitian terhadap Syuzuz dan 'Illat pada Sanad Hadis ad-Darimi}

Hadis syaz menurut bahasa adalah hadis yang menyendiri, artinya menyendiri dari mayoritas. Sedangkan menurut istilah hadis syaz adalah hadis yang diriwayatkan oleh seorang perawi yang siqah/makbul, tetapi menyelisihi perawi yang lebih utama atau yang lebih siqah darinya. Kelebihan tersebut bisa dilihat dari sisi kedabitannya, jumlah perawi yang menyelisihinya atau sisi-sisi lain yang menyebabkan riwayatnya dianggap syaz. ${ }^{29}$

\section{e. Kualitas Hadis yang ditakhrij oleh ad-Darimi}

Menurut hemat penulis bahwa derajat hadis di atas adalah sahih, berdasarkan beberapa alasan, antara lain:

1. Semua perawinya bersifat adil dan dabit.

2. Semua sanadnya bersambung-sambung, meskipun sebagian perawi ada yang menggunakan metode 'an'anah.

3. Tidak ditemukan adanya ilat dan syuzuz pada sanad dan matan hadis tersebut.

4. Hadis tersebut juga diriwayatkan oleh Imam al-Bukhari dan Muslim dalam kitab Sahih-nya, begitu juga kitab-kitab Sunan yang lain, meskipun

${ }^{28}$ Pentahkik kitab Sunan ad-Dirimi juga memberikan penilaian yang sama yaitu sahih alisnad. Lihat Abu Muhammad 'Abdullah Ibn 'Abdirrahman ad-Darimi as-Samarqandi, Sunan adDarimi, tahkik Husain Sulaim ad-Darani, (Riyad: Dar al-Mugni Li an-Nasyr, 2000 M), jilid. 1, h. 529.

${ }^{29}$ At-Tahhan, Taisir, h. 123. 
dengan redaksi yang sedikit bervariasi tetapi menunjukkan makna yang sama.

5. Selain itu, jalur sanad hadis di atas bertemu pada rawi yang sama yaitu Sulaiman al-A'masy dan selanjutnya sampai kepada rawi paling atas, Huzaifah Ibn al-Yaman. Wallahu a`lam.

\section{Kesimpulan}

Dari pembahasan di atas dapat disimpulkan beberapa kesimpulan, sebagai berikut:

Hadis tentang kencing berdiri ditemukan dalam sejumlah buku induk hadis, antara lain al-Kutub at-Tis`ah. Selain itu, hadis yang ditakhrij oleh Imam ad-Darimi kualitasnya sahih, berdasarkan lima kriteria hadis sahih, sebagaimana yang dijelaskan oleh ulama mustalah Hadis. Untuk menemukan hasil yang lebih maksimal, tentunya tidak cukup hanya dengan meneliti satu jalur hadis saja, melainkan dilakukan penelitian terhadap seluruh jalur hadis yang ada. Hal ini menuntut kajian lebih mendalam dan komprehensif, agar penelitian tersebut benar-benar dapat dipertanggungjawabkan secara ilmiyah dan penuh tanggungjawab. Untuk itu, diharapkan kepada peneliti selanjutnya agar meneliti jalur-jalur lain, yang belum disepakati oleh seluruh ulama hadis atas kesahihannya, atau minimal mayoritas ulama hadis.

\section{Pustaka Acuan}

Mahmud at-Tahhan, Usul at-Takhrij wa Dirasatu al-Asanid, Riyad: Maktabah alMa`arif, 1996 M, cet. 3.

Abu `Abdillah Muhammad ibn Isma`il al-Bukhari, Sahih al-Bukhari, t.t.p. :Dar Tauq an-Najat, $1422 \mathrm{H}$, cet. 1.

Muslim Ibn al-Hajjaj, Sahih Muslim, Beirut: Dar Ihya' at-Turas al-'Arabi: t.t.t., jilid. 1 .

Muhammad Ibn 'Isa at-Tirmizi, Sunan at-Tirmizi, Beirut: Dar al-Garb al-Islamiy, 1998 M, jilid. 1.

Abu 'Abdirrahman Ahmad Ibn Syu'aib an-Nasa'i, Sunan an-Nasa'i, Halb: Maktab al-Matbu`at al-Islamiyah, 1986 M, jilid. 1. 
Abu Daud Sulaiman Ibn al-Ays`asy as-Sijistiayani, Sunan Abi Daud, Beirut: alMaktabah al-'Asriyah, t.t.t., jilid. 1.

Ibn Majah Abu 'Abdillah, Sunan Ibn Majah, t.t.p.: Dar Ihya' al-Kutub al'Arabiyah, t.t., jilid. 1.

Abu 'Abdillah Ahmad Ibn Muhammad Ibn Hanbal asy-Syaibani, Musnad Ahmad, Riyad: Muassasah ar-Risalah, jilid. 38, $2001 \mathrm{M}$.

Abu Muhammad 'Abdullah Ibn 'Abdirrahman ad-Darimi as-Samarqandi, Sunan ad-Darimi, Riyad: Dar al-Mugni Li an-Nasyr, 2000 M, jilid. 1.

Ahmad Ibn 'Ali Ibn Hajar al-'Asqalaniy, Taqrib at-Tahzib, Riyad: Dar al'Asimah, $1416 \mathrm{H}$, cet. 1 .

Syamsuddin Muhammad Ibn Ahmad az-Zahabiy, Mizan al-I tidal, Beirut: Dar alKutub al-'Ilmiyah, 2008 H, cet. 2.

Abu Muhammad 'Abdurrahman ar-Razi Ibn Abi Hatim, al-Jarh wa at-Ta'dil, Beirut: Dar Ihya' at-Turas al-'Arabi, 1952 H, jilid IV, cet. 1.

Yusuf Ibn 'Abdirrahman Abu al-Hajjaj Jamaluddin al-Mizzi, Tahzib al-Kamal Fi Asma 'i ar-Rijal, Beirut: Mu'assasah ar-Risalah, 1980 M, jilid XII, cet. 1.

Syamsuddin Muhammad Ibn Ahmad az-Zahabiy, al-Kasyif, Jeddah: Mu'assasah 'Ulum al-Qur'an, 1992 H, jilid. 1, cet. 1.

Mahmud at-Tahhan, Taisir Mustalah al-Hadis, Riyad: Maktaba al-Ma`arif, 2004 M, cet. 10 .

az-Zahabiy, Mizan al-I`tidal, Beirut: Dar al-Ma`rifah, jilid. II, 1963 M, cet. 1.

Abu Muhammad 'Abdullah Ibn 'Abdirrahman ad-Darimi as-Samarqandi, Sunan ad-Darimi, tahkik Husain Sulaim ad-Darani, Riyad: Dar al-Mugni Li anNasyr, 2000 M, jilid. 1. 